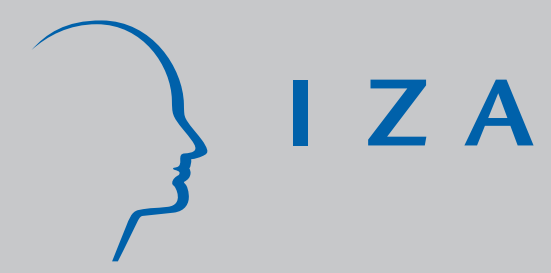

IZA DP No. 7713

Individual Behavior as a Pathway between

Early-Life Shocks and Adult Health:

Evidence from Hunger Episodes in Post-War Germany

Iris Kesternich

Bettina Siflinger

James P. Smith

Joachim K. Winter

November 2013 


\title{
Individual Behavior as a Pathway between Early-Life Shocks and Adult Health: Evidence from Hunger Episodes in Post-War Germany
}

\author{
Iris Kesternich \\ University of Munich
}

Bettina Siflinger

University of Mannheim

\section{James P. Smith}

RAND and IZA

\author{
Joachim K. Winter \\ University of Munich
}

\section{Discussion Paper No. 7713 \\ November 2013}

\author{
IZA \\ P.O. Box 7240 \\ 53072 Bonn \\ Germany \\ Phone: +49-228-3894-0 \\ Fax: +49-228-3894-180 \\ E-mail: iza@iza.org
}

\begin{abstract}
Any opinions expressed here are those of the author(s) and not those of IZA. Research published in this series may include views on policy, but the institute itself takes no institutional policy positions. The IZA research network is committed to the IZA Guiding Principles of Research Integrity.

The Institute for the Study of Labor (IZA) in Bonn is a local and virtual international research center and a place of communication between science, politics and business. IZA is an independent nonprofit organization supported by Deutsche Post Foundation. The center is associated with the University of Bonn and offers a stimulating research environment through its international network, workshops and conferences, data service, project support, research visits and doctoral program. IZA engages in (i) original and internationally competitive research in all fields of labor economics, (ii) development of policy concepts, and (iii) dissemination of research results and concepts to the interested public.
\end{abstract}

IZA Discussion Papers often represent preliminary work and are circulated to encourage discussion. Citation of such a paper should account for its provisional character. A revised version may be available directly from the author. 
IZA Discussion Paper No. 7713

November 2013

\title{
ABSTRACT
}

\section{Individual Behavior as a Pathway between Early-Life Shocks and Adult Health: Evidence from Hunger Episodes in Post-War Germany*}

\begin{abstract}
We investigate long-run effects of episodes of hunger experienced as a child on health status and behavioral outcomes in later life. We combine self-reported data on hunger experiences from SHARELIFE, a retrospective survey conducted as part of SHARE in Europe in 2009, with administrative data on food supply (caloric rations) in post-war Germany. The data suggest that individual behavior is a pathway between early life shocks and adult health: We find that those who experienced hunger spend a larger fraction of income on food. Taken together, our results confirm that in addition to the well-documented biological channel from early life circumstances to adult health, there is also a behavioral pathway.
\end{abstract}

JEL Classification: $\quad$ I10

Keywords: war, health, income

Corresponding author:

James P. Smith

RAND Corporation

1776 Main Street

PO Box 2138

Santa Monica, CA 90407

USA

E-mail: smith@rand.org

\footnotetext{
* This paper uses data from SHARELIFE release 1, as of November $24^{\text {th }} 2010$, SHARE wave 2 release 2.5.0, as of May $24^{\text {th }} 2011$, and SHARE release 1.1.1, as of March $28^{\text {th }}$ 2013. The SHARE data collection has been primarily funded by the European Commission through the $5^{\text {th }}$ framework and $6^{\text {th }}$ framework program. SHARELIFE was supported through the $7^{\text {th }}$ framework program. Additional funding from the U.S. National Institute on Aging as well as from various national sources is gratefully acknowledged. Kesternich recognizes funding by the DFG through SFB-Transregio 15.
} 


\section{Introduction}

The fetal origins hypothesis establishes a biological link between health shocks experienced in utero and other sensitive periods of childhood and adult health (Smith (1999) and Almond (2011) provide excellent overviews). Through adverse events, in particular undernutrition, the fetus is programmed to have certain metabolic characteristics which then impact health in later life. A well-established biological channel explains these effects, at least in part: Hunger has long-run effects if under-nutrition occurs in certain sensitive periods of growth or fat storage required for later growth (Barker (2004)). ${ }^{1}$

In this paper, we study individual behavior as a complementary pathway between early-life shocks and adult health. While there is an emerging literature on cognitive skills as a link between childhood circumstances and adult outcomes, other behavioral channels have received little attention (Heckman (2012)). We argue that an early-life event- a prolonged experience of severe hunger during childhood - is not only an immediate negative biological shock to the health stock but also affects subsequent behavior over the entire life-cycle, which impacts health at older ages. Thus, a one-time shock can change the entire future path of health investments and health over time. Such a mechanism provides an additional rationale for the (causal) effect of early life shocks on late-life health outcomes (and also on SES outcomes which are a function of the time path of health). We illustrate this channel using retrospective data on long-run effects of a major health shock in Germany: the hunger periods experienced throughout the country in the immediate post-World War II years.

To test the hypothesis of a behavioral channel linking early-life events and adult outcomes, one would like a panel dataset containing information on health, health shocks and health-related behaviors over long periods of time, ideally starting at birth and extend-

\footnotetext{
${ }^{1}$ There is evidence that hunger later in childhood have lasting health effects (van den Berg et al. (2012)).
} 
ing through adult life. Such datasets unfortunately do not exist. Our research relies instead on retrospective life data from the European Survey of Health, Aging, and Retirement in Europe (SHARE) that recently became available. SHARE covers representative samples of the population aged 50 and over in 13 European countries, with about 20,000 observations. In this analysis, we concentrate on Germany which was not only among the countries most affected by World War II, but also by hunger (Kesternich et al. (forthcoming)). We also make extensive use of external data on amounts of calories available in different regions of Germany in the postwar period.

The shock we exploit is hunger in post-World War II Germany, and the subsequent behavior we consider is food consumption. Our hypothesis is that individuals who suffered from hunger in early life "eat more" in later life as a precaution against the risk of new hunger episodes. ${ }^{2}$

In this paper, we look beyond short-run impacts by suggesting a behavioral mechanism whereby early-life hunger predicts food consumption late in life. Engel curves for food consumption are significantly different for individuals who suffered from hunger and those who did not. We find that the effect of hunger on food shares is strongest for low-income individuals. This confirms our assumption that poorer individuals are more at risk of ever becoming hungry again and thus eat more as a type of precautionary measure.

An important methodological contribution is that we do not only rely on selfreported measures of hunger, but also on data on food supply (measured in calories available per capita per month, which varied in postwar Germany not only over time but by occupation zone). Our data on caloric rations indicate that self-reports are indeed a reliable

\footnotetext{
2 Several papers use retrospective data on childhood circumstances and adult outcomes in SHARELIFE to study long-run effects of early-life shocks across Europe (Halmdienst and Winter-Ebmer (2012); Havari and Peracchi (2011); van den Berg et al. (2012)); and. Juerges (2013). None of these papers or our own earlier research (Kesternich et al. (forthcoming) consider the behavioral channel analyzed in this paper.
} 
measure for the experience of hunger episodes as these self-reports accurately match both regional and time variation of the hunger episodes.

This paper is divided into five sections. The next section documents the main episodes of hunger in pre- and postwar Germany and the principal economic reasons for those hunger episodes. Section 3 highlights the central elements of the main data on which we rely in this research. It shows the correspondence between retrospective self-reported episodes of hunger and our objective contemporaneously reported caloric data. In the following section 4, we model the relationship between childhood hunger and caloric restriction on later life food consumption. We summarize our main conclusions in section 5.

\section{The nutritional situation in Germany during and after World War II}

In Germany, food rationing using food stamps started just before WWII on August 28, 1939. From this date until the end of the war, Germany's food supply and distribution was organized centrally, and food and many other things could only be bought with food stamps (Schlange-Schoeningen (1955)). From the start of WWII to the end of 1941, daily rations of food were quite high, just below 2,500 kcal (Eitner (1991)). Thus, cuts were small for those who had not lived in luxury before the war. Starting at the end of 1941 , food rations were reduced to about 2,000 kcal per day. Increased workloads, night shifts, and stress of bombing decreased time spent sleeping and raised caloric needs (Eitner (1991)). ${ }^{3}$ Severe famine conditions started towards the end of WWII, continued through the first years of allied occupation, and lasted until $1948 .^{4}$

\footnotetext{
${ }^{3}$ Some of the decrease was due to productive capacity being channeled into war production and to men being absent (this work was done often by elderly women and prisoners of war or forced laborers).

${ }^{4}$ The first hunger oedema was reported in the summer of 1945 (Farquharson (1985))
} 
There were several reasons for this famine. First, with the end of the war, centralized war-time food distribution and production in Germany completely collapsed. The administrations of four Allied occupation zones (British, U.S., French, and Soviet) set and enforced caloric goals separately for their respective regions. The official rations lay between 1200 and $1400 \mathrm{kcal}$ per day in 1946 and 1947 (Schlange-Schoeningen (1955)). Since the German currency was not backed by a national government, it was basically without value, and trade took place against food stamps or other products.

Second, agricultural productivity dropped to about $2 / 3$ to $3 / 4$ of the pre-war levels (Liebe (1947)). The main reasons were lack of fertilizers, large-scale war destruction of farm buildings and machinery, and death and displacement of workers. In total, the harvest of 1946 was at about 67 percent, the one of 1947 at about 50 to 55 percent of a normal harvest (Haeusser and Maugg (2011)).

Agricultural output across the four occupation zones varied. The Soviet and French zones did worse than the UK and U.S. zones, as large parts of local production (fertilizer, meat, milk) were confiscated and distributed to military personnel or sent to occupying countries (Schlange-Schoeningen (1955)). Until the French zone was united with the UK and US zone, its inhabitants faced a worse nutritional situation than their counterparts in the Anglo-Saxon zones (about 200-300 kcal per day less). As the war was especially atrocious for the Soviet Union (losing more than twenty million people), the attitude towards the occupied German country was even harsher. Thus, the nutritional situation was worse in the Soviet zone.

Besides the drop in agricultural output in today's territory, Germany lost its pre-war Eastern parts to Poland, the Czech Republic and the Soviet Union. These Eastern parts were a vital part of the German agricultural system. Until the end of the war, about 30 percent of agricultural produce and inputs of agricultural production, e.g. seeds, were pro- 
duced in the Eastern part of the German Reich (Rothenberger (1980)) ${ }^{5}$. Problems with agricultural production could not be attenuated by food imports from other countries, since harvests were also bad in the traditional grain producing countries such as Canada, Australia and Argentina (Haeusser and Maugg (2011)).

Third, severe problems in food production were exacerbated by breakdowns of trade and transport within Germany. Before WWII, German agricultural production was fairly specialized due to differences in geography but there was ample trade of food products between different parts of Germany. Industries producing agricultural inputs, , relied on suppliers from all over the Reich (Rothenberger (1980)). After the war, trade between four occupation zones came to a virtual standstill, which amplified problems in food supply due to a shortage in inputs such as seeds and fertilizers.

Large-scale destruction of transport infrastructure (roads, railroad tracks, and bridges) was another reason for breakdowns of trade between and within occupation zones. Transportation by barges on rivers and by rail was nearly impossible after the war, as debris of destroyed bridges blocked major waterways ${ }^{6}$. Individuals resorted to basic means of transport (horse-drawn transport, and handcarts (Farquharson (1985)).

Moreover, trade was hampered as occupation zones were unequally endowed with agricultural potential. This led to zones of different nutritional potential, each of which had to meet its own demand completely from local production (Schlange-Schoeningen (1955)). Trade was made impossible by the fact that the command of allied governments ended at these zone frontiers, so the steering the economy ended there as well (Rothenberger

\footnotetext{
5 Germans living in these regions, mainly farmers, were forced to move westwards. While inhabitants of other parts of Poland and the Czech Republic were moved there and took over the farms, production after the war was only at about 50 percent of what had been produced before (Rothenberger (1980)).

${ }^{6}$ In the British occupation zone, 1,000 out of 13,000 km of railway tracks were operational in spring 1945.
} 
(1980)). The three Western zones were completely blocked off from the Eastern zone that had a higher nutritional potential. ${ }^{7}$

In addition to these supply side problems, there was increased demand in nutritional products, at least in Western regions. About 10 million refugees from the formerly Eastern parts of the German Reich flooded into the remaining parts (Kulischer (1948)). A large share of these refugees was hosted by the British occupation zone.

In 1946, the famine situation improved through food relief shipments from the United States. Food relief shipments to Germany in the form of CARE Package shipments to individuals started to be allowed from June 1946. Slowly, trade and agricultural production resumed. The occupation governments understood how big an impediment the condition of the transport sector was, and efforts to restore this sector had been successful from 1947 onwards (Haeusser and Maugg (2011)). With the unification of Western occupation zones and a currency reform on June 20,1948, the nutritional situation of West Germans significantly improved and supply picked up considerably. In the Eastern part, there was a land and currency reform. The economy was transformed into a socialist system, and improvements in food supply were slower.

\section{Data}

In this section, we present our data. We first describe the individual-level survey data that provide both retrospective information on early-life circumstances and adult outcomes. We then discuss sources of administrative data caloric rations and how we constructed the

\footnotetext{
${ }^{7}$ There were some attempts of the British zone to trade steel against food produced in the Soviet zone, but largely these attempts failed (Farquharson (1985)). The French saw their occupation zone as a separate entity so that the economic relationships with the other zones were cut to a large extent.
} 
monthly and regional food supply variables. Finally, we describe how the analytic sample was constructed from these two main sources of data.

\section{1 SHARE and retrospective early-life data from SHARELIFE}

SHARE is a multidisciplinary cross-national panel interview survey on health, socioeconomic status, and social and family networks of individuals aged 50 or over in continental Europe. The original 2004/2005 SHARE baseline included nationally representative samples in 11 European countries (Denmark, Sweden, Austria, France, Germany, Switzerland, Belgium, Netherlands, Spain, Italy, and Greece) drawn from population registries, or from multi-stage sampling (http://www.share-project.org/). For these countries, a second wave of data collection took place in 2006 , the third wave of data collection on this panel (SHARELIFE) was completed in 2008, and a fourth wave was conducted in 2010. In addition to a standard set of demographic attributes, SHARE includes health variables (selfreported health, health conditions, and health behaviors), SES variables including net family income and education, and expenditures on food both inside and outside the home.

SHARELIFE provides retrospective histories based on life history calendar methods including region living, childhood SES, and experiences of hunger. Information in the life history includes family composition and type of home (number of rooms, running water, toilet, etc), number of books, and occupation of father. SHARELIFE provides data on within country region of residence and type of housing during the full life of respondents (childhood and adulthood). Respondents were asked about region and type of accommodation when born. Then they were asked if they ever moved and, if yes, when, where and why. The questions were asked in a loop for each move. 


\subsection{Caloric rations and self-reported hunger}

In SHARELIFE, respondents were asked: “(Looking back at your life), was there a period when you suffered from hunger?" If respondents said "yes", they were asked when it started and ended so we know duration of hunger episodes. Figure 1 shows the percent of respondents suffering from hunger by time in all SHARE countries in WWII. Hunger periods respondents reported coincide closely with historical facts: Hunger prevalence picks up with the war's end for Austria and Germany and during the war for other countries. Germany has by far the most respondents reporting suffering from hunger.

Our main reason for choosing Germany is that during and after WWII, food production and supply was under state-control and organized centrally. Besides individuals' selfreports on periods of hunger, we collected administrative data on official caloric rations in War Time Germany, the occupation zones, and East and West Germany. Our data include caloric measures from January 1929 to December 1971.

Since food supply was not restricted in Germany before 1939, we use average caloric intake per day from the League of Nations for Germany (Liebe (1947)). From 1939 till the end of WWII the rationing period was one year and new caloric rations were determined in September (Schlange-Schoeningen (1955)).

In April/May 1945 the Allies divided the remaining German territory into four occupation zones independently administered by the USA, Great Britain, the Soviet Union, and France. Thereafter, official caloric rations were distinguished by occupation zone. Rationing periods were updated every four weeks in all but the Soviet zone leading to considerable variation of official caloric rations by region and time. Changes in official rations were less regular in the Soviet zone (Schwarzer (1995)).

In May 1947, the UK and US zones merged into a united economic territory, providing identical daily caloric rations every four weeks. On June 201948 a currency reform 
took place in Western zones leading to an immediate improvement in food supply: In July 1948 official caloric rations were about $500 \mathrm{kcal}$ per day higher compared to the month before (Rothenberger (1980)). In 1949 the UK, US, and French zones merged into the Trizone which became the Federal Republic of Germany. From 1950, food rationing was completely eliminated and recommended levels of about $3000 \mathrm{kcal}$ per day were again achieved. In the German Democratic Republic however food supply was still problematic so that food rationing was not abolished before 1956 (Schwarzer (1995)).

We merge the monthly caloric rations to the respondents' region of residency by year. ${ }^{8}$ We illustrate the relation between self-reported hunger and official caloric rations in Figure 2. The upper line presents variation in official caloric ration from January 1930 to January 1970. The lower line displays hunger self-reports. The two measures vary quite closely over time. When official caloric rations start to decrease in 1939, the fraction of respondents reporting hunger increases at the same time. The official caloric intake achieves its minimum in the summer months of years 1946/47.

To account for heterogeneous effects of hunger episodes by stages during childhood (infant, child, youth), we generate age-specific caloric intakes at age 0-3, 4-10,11-16, and 016. We construct a dummy variable which takes the value one if respondents had experienced at least one month below a specific daily caloric threshold. As main threshold we use a value of $1500 \mathrm{kcal} /$ day which corresponds to a measure of the metabolic rate at rest. This rate was estimated to lie to be between 1,500 kcal and 1,637 kcal (Boldorf (1998)). Administrative data are not afflicted with memory misreports, and are exogenous to the individual.

\footnotetext{
${ }^{8}$ The state of Baden-Wuerttemberg was split up between the US zone and the French zone. Since about two third of the territory and the state's largest cities fall in the US zone, we assign all respondents from BadenWuerttemberg to the US zone
} 
If self-reports are reliable measures for experienced hunger, we should find a significant correlation between caloric rations and self-reports. Thus, we conduct a first-stage analysis regressing self-reported hunger on age-specific caloric rations. Self-reported hunger is a binary variable that takes the value one if a respondent suffered hunger. The official caloric intake is a binary variable which takes the value one if the respondent experienced at least one month of less than 1500 calories per day at a specific age. To control for regionspecific differences we include occupation zones dummies. The results in Table 2 suggest a strong correlation between the official caloric rations and self-reported hunger for all age groups. The estimated coefficient the age group 0-16 implies an increase in the probability of suffering from hunger by 17.8 percentage points if the average daily caloric intake in one month in this age group was less than 1500 calories per day. Effects are strongest in age group 11-16, followed by age 4-10, with the weakest effect not surprisingly given their age at the time in the age 0-3 group.

Interestingly, we find significantly negative effects of living in the US zone compared to all other zones on the probability of suffering from hunger even after controlling for available calories for all ages except the youngest. As noted on page 5, the conditions in the French and Soviet zones were harsher than in the British and US zones as food was confiscated. In addition, the Soviet Zone was much stricter in measuring food production already at the local production sites. The difference between the British and US zones lie on the one hand in the fact that cities were more heavily destroyed in the British zone, but also in the ways the administration was organized: While the US zone relied on a federal idea and soon began to entrust the local organization to the local administration, the British zone was organized centrally, so that changes came about much more slowly than in the US zone (Schlange Schöningen, 1955). Given these results, we presume that the official caloric rations are a good measure to proxy self-reported hunger. In contrast to the respondents' 
hunger reports, the calories used here are exogenous to the individual and not affected by any recall bias. ${ }^{9}$

Lastly, in order to show that the experience of hunger is not just a measure for low childhood SES we analyze how our hunger measure varies by SES. In figure 3, we show selfreported hunger by SES, and we see that, although high SES individuals do a little worse, hunger was a universal phenomenon across all SES groups in Germany at that time.

\subsection{Construction of the analytic dataset}

For the analysis we consider a sample of 1,785 respondents from Germany that participated in SHARELIFE, and either in wave 2 or wave 4 of the SHARE survey. Information from wave 2 is used if the respondent did not participate in wave 4 , or if the required information is not available in wave 4 .

Official caloric rations are available for the post-war German territory and vary over time as well as over the occupation zones. Therefore, we exclude respondents that were not born within today's German borders. Treatment periods refer to the years 1945-48 when Germany suffered from extreme food shortages. Since we are interested in the consequences of under-nutrition during childhood, we exclude respondents that were born before January 1929 and after December 1960.10 Our final sample consists of 1,350 respondents.

To measure food consumption behavior we generate a food share variable as the fraction of household food expenditures in total household net income. SHARE interviews (wave 2 and 4 ) collect data on household food consumption expenditures by asking for the

\footnotetext{
${ }^{9}$ Official caloric rations do not provide inter-individual variation, thus they might not be good enough for serving as an instrument.

${ }^{10}$ Individuals born before 1929 might have also been affected by WWI, or the world economic crisis and thus show a differential food consumption behavior.
} 
average monthly amount spent on food at home and outside home during the last 12 months. We add the values of these two items and obtain the total household food expenditures as the enumerator of the share. The denominator is defined by the total household net income in an average month which SHARE collects using a one-shot question.

Due to potential misreports and implausible values in the income question, we trim the income distributions of waves 2 and 4 at the $5^{\text {th }}$ and $95^{\text {th }}$ percentiles, obtaining 1,087 individuals with a food share value. In a next step, the food share distribution is trimmed by eliminating values that are below the $5^{\text {th }}$ and above $95^{\text {th }}$ percentile ${ }^{11}$. Our final analytic data set consists of 974 observations with valid food share and income values.

We generate the logarithm of the total household net income as well as two income splines splitting up the income distribution at its median. We moreover compute a number of interactions between these different income measures and self-reported hunger as well as the caloric threshold dummies. Table 1 provides the descriptive statistics on the main outcomes of interest, income and hunger quantities, and the control variables.

\section{Empirical strategy and results}

The objective of this study is to show that individual behavior can be a pathway between an early life shock - hunger - and later life health outcomes. First, we analyze food share as the behavioral component which is defined as the share of household food expenditure (at home and outside the house) in total household net income. Our measures for experiencing a period of under-nutrition are a binary indicator variable, based on self-report, for whether the respondent suffered from hunger, and measures of calorie supply that vary across

\footnotetext{
${ }^{11}$ The trimming of the distributions guarantees that no implausible shares are left in our data. Such values occur if respondents report e.g. yearly instead of monthly food expenditures or income values.
} 
occupation zones and by month. In the analysis, we exploit the information on whether an individual lived in a region when the official caloric rations were below $1500 \mathrm{kcal}$ per day for at least one month.

In a second step we specify models that relate early life hunger and later life obesity. To see whether the food spending translates into measures of body weight, we use the probability of being obese as adult health measure, and estimate the same specifications as for the behavioral model.

\subsection{Engel curves}

We start by specifying the link between hunger episodes during childhood and food shares. To model food shares, we use a variant of the well-known parametric Working-Leser specification of an Engel curve.

Engel curves state that fractions of income spent on food decreases as income increases for given tastes and preferences. An Engel curve is assumed to be shape-invariant, suggesting that changes in policies and demographic variables shift and scale the function without altering overall shape (Blundell, et al. (2007)). We assume that experiencing hunger during childhood represents such an Engel curve shifter. Individuals might change spending on food in response to experience of hunger leading to higher food shares in adult life. We analyze this relation by interacting hunger measures with the logarithm of the household income. Moreover, it has been shown food expenditures are not necessarily a linear function of income (Lewbel 2006).

In our main specification, we model nonlinearities in income by introducing splines of the logarithmic income that are split at the median income. In addition, we interact these income splines and the hunger self-reports, allowing us to detect different reactions for low and high 
income households to the experience of hunger (Lewbel (2010)). The Engel curve equation for Tables 3 and 4 as well as Tables A.1 and A.2 is

$F S_{i}=\beta_{0}+\beta_{1} H_{i, a g e}+\beta_{2} I(<p 50)_{i}+\beta_{3} I(\geq p 50)_{i}+\beta_{4} H_{i, a g e} \times I(<p 50)_{i}+\beta_{5} H_{i, a g e} \times I(\geq p 50)_{i}+x_{i}^{\prime} \gamma+\epsilon_{i}$

where $I_{i}$ refers to the logarithm of total household net income, $H_{i}$, age is self-reported hunger at a specific age, $\mathrm{I}(<\mathrm{p} 50)_{\mathrm{i}}$ and $\mathrm{I}(\geq \mathrm{p} 50)_{\mathrm{i}}$ are the splines of the logarithmic income that split the corresponding distribution at its median. The coefficients $\beta_{4}$ and measure $\beta_{5}$ measure the impact of suffering from hunger along the upper and the lower $50 \%$ quantiles of the income dimension. $\mathbf{x}_{\mathbf{i t}}$ is a vector of covariates, and $\varepsilon_{\mathbf{i}}$ is the error term.

Typically, the food share distribution is asymmetric with some respondents having high food expenditures, but very low income. A least squares estimator such as OLS may not be robust against unusual points in the distribution leading to a poor fit of least squares estimates. In Tables A1 and A2 as a robustness check, we estimate median regressions using the minimum absolute deviations method (Basset and Koenker (1978)).

$F S_{i}=\beta_{0}+\beta_{1} H_{i, a g e}+\beta_{2} I_{i}+\beta_{3} I_{i}^{2}+\beta_{4} H_{i, a g e} \times I_{i}+\beta_{5} H_{i, a g e} \times I_{i}^{2}+\mathrm{x}_{i}^{\prime} \gamma+\epsilon_{i}$

The general optimization problem can be formulized as (see Basset and Koenker (1978))

$$
\underset{\theta}{\arg \min } \sum_{y_{i} \geq \mathbf{x}_{i}^{\prime} \boldsymbol{\theta}} \pi\left|y_{i}-\mathbf{x}_{i}^{\prime} \boldsymbol{\theta}\right|+\sum_{y_{i}<\mathbf{x}_{i}^{\prime} \boldsymbol{\theta}}(1-\pi)\left|y_{i}-\mathbf{x}_{i}^{\prime} \boldsymbol{\theta}\right|
$$

$\pi$ denotes the chosen quantile, and $\theta=(\beta, \gamma)^{\prime}$ is a vector of parameters to be estimated. For the median regression $\pi=0.5$, a symmetric weighting of observations with positive and negative residuals. The median regression minimizes the sum of absolute deviations, $\Sigma_{\mathrm{i}}\left|\varepsilon_{\mathrm{i}}\right|$, as defined in equation (3), and yields an asymptotically normally distributed estimator. The standard errors of this median estimator are clustered on the household level.

Table 3 presents results from estimation of food shares on hunger, logarithm of household net income, interactions of hunger with median logarithmic income splines, and other covariates. Income has a strong negative impact on food shares reflecting the standard Engel curve relation (Blundell, et al. (2007) on all age bands, hunger increases food 
shares especially for those below median income. Let us first consider our main estimates for everybody who experienced hunger between 0 and 16 (Table 3, column 1) whose predicted values are also depicted in Figure 4 (a). For those respondents who have not suffered from hunger, if income increases by 1 percent, food share decreases for 0.049 for low-income households, and a steeper decrease of 0.081 for high income households. The experience of hunger significantly increases the share of household food spending as can be seen by the positive and significant main effect of hunger.

We find strong positive statistically significant positive impacts of hunger main effects on food shares for ages 0-3 and 4-10: This relationship is driven by those whose log net household income is below or above the sample median (we see a qualitatively similar prediction for our squared interactions in Figure 5). As income increases towards the median income in these groups, the differences between those who experienced hunger and other respondents becomes progressively smaller, and it increases again for high incomes.

Next, we replace $\mathrm{H}_{\mathrm{i}}$ in equation (1) with the experiencing at least one month below a threshold value of $1500 \mathrm{kcal}$ per day. In contrast to self-reported hunger, which might be correlated with unobserved factors such as growing up in a family of farmers, caloric rations are exogenous to the individual as they were fixed by administrations of occupation zones. Table 4 reports the results. The impact of log net household income on food share is similar in size as in regressions for hunger self-reports. The main effect of months below $1500 \mathrm{kcal}$ per day now is significant for our main specification (age 0-16), as well as for children of $04-10$ years. The higher the number of months below 1500 kcal per day to which the individuals were exposed, the higher amounts spent on food relative to their income. Moreover, the interaction terms of the caloric measure and income are significantly different from zero. These results confirm the findings from the hunger regressions in Table 3. They suggest that individuals who suffered from hunger have a different food con- 
sumption behavior as adults than those who did not experience hunger, or had hunger later in life. These differences are stronger for those who have either low or high net household incomes and are amplified for a larger number of months below the threshold of $1500 \mathrm{kcal}$ per day.

We illustrate the relation found in Tables 2 and 3 by plotting food share predictions for hunger and caloric rations at age 0-16 against log net household income. Figure 4(a) represents Engel curves stratified by whether the individual suffered from childhood hunger or not. For both groups we find an increasing food share as income decreases. Hunger differences in slopes of income coefficients are significant both for very low and very high incomes. Those with a log income below the median spend a considerably higher fraction of their income on food when they experienced hunger as a child than those who did not. With increasing income, the food share of hunger and no hunger group converge for median incomes and then diverge again. The findings from figure 4(a) underline our results of behavioral differences in food consumption due to having suffered from hunger (table 2).

In figure 4(b) we now stratify by whether respondent ever experienced a month at age 0-16 at which the official caloric ration was below $1500 \mathrm{kcal} / \mathrm{day}$. The differences between groups are even larger for the low income group, but also disappear as income is closer to the median and then increase again for high incomes. So, individuals who suffered from hunger spend a much higher amount of their income on food when their income is low. But as their income elasticity is higher in absolute terms than that of those respondents who have not suffered from hunger, our respondents who have suffered from hunger show similar spending than those when close to the median income. However, above the median income our respondents who have not suffered from hunger substitute away from food more as they get richer than do our respondents who did indeed suffer from hunger . Both graphics in figure 5 confirm our hypothesis that those who have suffered from hunger 
behave differently in terms of food consumption if they hold low incomes. The more income respondents earn, the more the behavioral consumption differences decrease. Thus, having suffered from hunger might change individuals' behavior which in turn might have consequences on later life health outcomes. One explanation for why we only see significant changes in food consumption for low-income individuals is that these individuals precaution against the risk of new hunger episodes.

One possible limitation of the analysis to date is that the childhood experience of hunger and childhood exposure to caloric limitations is measured at the individual level while the outcome under investigation (food shares) is measured at the household level. For food shares, measurement of both the numerator (food expenditures) and the denominator (net household income) is at the household level. This is rectified in the analysis presented in table 5 where the household experience of hunger and caloric restriction below 1500 calories both during childhood ages 0-16 are modeled. In this model in addition to the individual childhood experience we add a set of parallel variables for the spouse (if any) childhood experience.

The main effects of the childhood experience of hunger of the respondent and spouse are virtually identical although the statistical power of the spousal effect is weaker no doubt to smaller sample sizes. For caloric restrictions, the evidence is much stronger that both respondent and spousal effects of caloric restrictions during childhood matter and the relationships with household income are similar.

Given the evidence of a behavioral effect of hunger, we will show in the next section that food consumption is not only the outcome, but serves as a channel for hunger periods as an adverse childhood shock. Our hypothesis is that having experienced hunger has an effect on late life outcomes that are transferred by food consumption as a behavioral com- 
ponent. If this is correct, we would expect that food share has an effect on health outcomes, once we control for hunger and income.

\subsection{Early-life Hunger Experiences and Adult Obesity}

We model the relationship between late life health and hunger experiences by specifying the following latent variable equation with splines of the logarithm of household net income, hunger, and its interactions.

$Y_{i}^{*}=\beta_{0}+\beta_{1} H_{i, a g e}+\beta_{2} I(<p 50)_{i}+\beta_{3} I(\geq p 50)_{i}+\beta_{4} H_{i, a g e} \times I(<p 50)_{i}+\beta_{5} H_{i, a g e} \times I(\geq p 50)_{i}+\mathrm{x}_{i}^{\prime} \gamma+u_{i}$

where $Y_{i}^{*}$ is latent health and $u_{i}$ is the error term. The coefficient $\beta_{1}$ is the main effect of having experienced hunger at specific ages and, $\beta_{4}$ and $\beta_{5}$ the interaction terms along the income dimension, capturing all possible channels including behavioral and physiological impacts.

To analyze whether the high food spending translates into higher weight, we estimate the probability of being obese is defined as a binary variable that takes the value one if a respondent has a body mass index (BMI) above 30, zero otherwise. Table 6 presents the results from an OLS estimation of the probability of being obese. Individuals who suffered from hunger at ages 0-3, 4-10 and 0-16 have a significantly higher probability of being obese than others. This link returns for individuals at the higher tail of the income distribution. The higher the household's income, the smaller becomes the effect of the hunger experience on obesity.

The results provide an important implication. An adverse hunger shock seems not to only affect health outcomes when the individual is still in utero (see Barker (1992), Lumey and Stein (1997)). Instead, the hunger experiences made during the whole age of childhood seems to have negative consequences on late life health. In particular, individuals who have suffered from hunger during adolescence show worse health outcomes later in life. 


\section{Conclusion}

In this study, we show that an adverse life event during childhood affects not only adult health outcomes but also individuals' behavior at older ages (and thus presumably over the whole life-cycle). While the health effects of shocks in utero and at various stages of childhood on adult health are well established, most of the existing literature focused on biological channels, with some recent research also investigating the effects of shocks on cognitive skills. Our results suggest another causal link: Retrospective survey data on hunger experiences in post-war Germany, combined with administrative data on food supply (caloric rations) during those times and detailed data on adult outcomes, show that relatively short periods of severe hunger affect not only health outcomes of older individuals (higher body weight and higher rates of obesity) but also food consumption patterns.

Our results further show that the behavioral effects vary with the age at which children were affected. In particular, ages 4-10 seem to be a sensitive period during childhood. This suggests that policy interventions focusing on this group of children might be particularly useful. This complements existing research that stressed biological channels for which the most sensitive periods of childhood are much earlier. If the pathways between early-life shocks and late-life outcomes are not only biological but also behavioral, then there are ampler possibilities to counteract these pathways.

We also contribute to the literature on endogenous preference formation. Our finding that preferences are not only influenced by preferences of parents or role models (Dohmen et al. 2011), but also by large shocks experienced during childhood and youth, provides a complementary explanation for a correlation of preferences between genera- 
tions. Perhaps more importantly, this result further strengthens the case for interventions in early childhood and adolescence (Heckman, 2012). 


\section{Results}

Table 1: Summary statistics

\begin{tabular}{|c|c|c|c|c|c|}
\hline VARIABLES & $\mathbf{N}$ & Mean & Std. dev. & Min & Max \\
\hline Food share & 974 & 0.22 & 0.10 & 0.05 & 0.77 \\
\hline Log HH net income & 1098 & 7.84 & 0.63 & 6.70 & 10.31 \\
\hline Quadratic log HH net income & 1098 & 61.82 & 10.44 & 44.93 & 106.28 \\
\hline log HH net income (lo) & 1098 & 7.56 & 0.26 & 6.70 & 7.75 \\
\hline log HH net income (hi) & 1098 & 0.28 & 0.48 & 0 & 2.56 \\
\hline
\end{tabular}

\section{Hunger measures}

hunger at age 00-16

hunger at age 00-03

hunger at age 04-10

hunger at age 11-16

ever below $1500 \mathrm{kcal}$ at age 00-16

ever below $1500 \mathrm{kcal}$ in utero

ever below $1500 \mathrm{kcal}$ at age 00-03

ever below $1500 \mathrm{kcal}$ at age 04-10

Ever below $1500 \mathrm{kcal}$ at age 11-16

1350

$0.12 \quad 0.33$

0.14

1350

1350

1350

1350

1350

1350

1350

1350

0.02

0.28

0.25

0.07

0.48

0.31

0.11

0.45

0.28

0.49

0.20

0.40

2.56

\section{Control variables}

US zone (at birth)

UK zone (at birth)

1350

\subsection{7}

0.45

1350

0.34

0.34

1350

0.33

0.23

1350

0.06

0.23

1186

65.34

7.62

1186

4327.21

1008

1350

0.47

0.5

1350

0.34

0.47

urban area (at birth)

Household size

1186

2.04

0.74

$\begin{array}{cc}0 & 1 \\ 0 & 1 \\ 0 & 1 \\ 0 & 1 \\ 49 & 82 \\ 2401 & 6724 \\ 0 & 1 \\ 0 & 1 \\ 1 & 7\end{array}$

Health outcomes

Health: being obese

1196

0.196

0.397

0 
Table 2: First stage OLS regressions of hunger at age $0-16,0-3,4-10$, and 11-16 on ever below $1500 \mathrm{kcal} /$ day

\begin{tabular}{|c|c|c|c|c|}
\hline VARIABLES & $\begin{array}{c}\text { (1) } \\
\text { Hunger } \\
\text { age 0-16 }\end{array}$ & $\begin{array}{c}(2) \\
\text { Hunger } \\
\text { age } 0-3\end{array}$ & $\begin{array}{c}\text { (3) } \\
\text { Hunger } \\
\text { age 4-10 }\end{array}$ & $\begin{array}{c}\text { (4) } \\
\text { Hunger } \\
\text { age 11-16 }\end{array}$ \\
\hline ever bel $1500 \mathrm{kcal}$ age $00-16$ & $\begin{array}{c}0.178^{* * *} \\
{[0.014]}\end{array}$ & & & \\
\hline ever bel $1500 \mathrm{kcal}$ age $00-03$ & & $\begin{array}{c}0.035^{* * *} \\
{[0.011]}\end{array}$ & & \\
\hline ever bel $1500 \mathrm{kcal}$ age $04-10$ & & & $\begin{array}{c}0.165^{* * *} \\
{[0.018]}\end{array}$ & \\
\hline ever bel $1500 \mathrm{kcal}$ age $11-16$ & & & & $\begin{array}{c}0.228^{* * *} \\
{[0.026]}\end{array}$ \\
\hline US zone (at birth) & $\begin{array}{c}-0.044^{* *} \\
{[0.021]}\end{array}$ & $\begin{array}{c}-0.003 \\
{[0.010]}\end{array}$ & $\begin{array}{c}-0.035^{* *} \\
{[0.017]}\end{array}$ & $\begin{array}{c}-0.033^{* *} \\
{[0.014]}\end{array}$ \\
\hline Soviet zone (at birth) & $\begin{array}{c}0.011 \\
{[0.022]}\end{array}$ & $\begin{array}{c}-0.012 \\
{[0.009]}\end{array}$ & $\begin{array}{c}0.013 \\
{[0.019]}\end{array}$ & $\begin{array}{c}0.009 \\
{[0.016]}\end{array}$ \\
\hline French zone (at birth) & $\begin{array}{c}-0.003 \\
{[0.038]}\end{array}$ & $\begin{array}{c}0.002 \\
{[0.019]}\end{array}$ & $\begin{array}{l}-0.029 \\
{[0.030]}\end{array}$ & $\begin{array}{c}0.009 \\
{[0.029]}\end{array}$ \\
\hline Constant & $\begin{array}{c}0.016 \\
{[0.012]}\end{array}$ & $\begin{array}{l}0.015^{* *} \\
{[0.008]}\end{array}$ & $\begin{array}{c}0.028^{* * *} \\
{[0.011]}\end{array}$ & $\begin{array}{c}0.024^{* * *} \\
{[0.009]}\end{array}$ \\
\hline $\begin{array}{l}\text { Observations } \\
\mathrm{R}^{2}\end{array}$ & $\begin{array}{l}1,350 \\
0.075\end{array}$ & $\begin{array}{l}1,350 \\
0.014\end{array}$ & $\begin{array}{l}1,350 \\
0.090\end{array}$ & $\begin{array}{l}1,350 \\
0.144\end{array}$ \\
\hline
\end{tabular}

Robust standard errors in brackets; *** $\mathrm{p}<0.01,{ }^{* *} \mathrm{p}<0.05,{ }^{*} \mathrm{p}<0.1$

We control for occupation zones at birth with UK zone being the reference category 
Table 3: OLS regression food share on self-reported hunger, log net HH income, interaction terms and squared interaction terms, ages 0-16, 0-3, 4-10, and 11-16

\begin{tabular}{|c|c|c|c|c|}
\hline VARIABLES & $\begin{array}{c}\text { (1) } \\
\text { foodshare }\end{array}$ & $\begin{array}{c}\text { (2) } \\
\text { foodshare }\end{array}$ & $\begin{array}{c}\text { (3) } \\
\text { foodshare }\end{array}$ & $\begin{array}{c}\text { (4) } \\
\text { foodshare }\end{array}$ \\
\hline log HH net income (lo) & $\begin{array}{c}-0.049^{* * *} \\
{[0.013]}\end{array}$ & $\begin{array}{c}-0.054^{* * *} \\
{[0.013]}\end{array}$ & $\begin{array}{c}-0.050^{* * *} \\
{[0.013]}\end{array}$ & $\begin{array}{c}-0.052^{* * *} \\
{[0.013]}\end{array}$ \\
\hline $\log \mathrm{HH}$ net income (hi) & $\begin{array}{c}-0.081^{* * *} \\
{[0.011]}\end{array}$ & $\begin{array}{c}-0.078^{* * *} \\
{[0.011]}\end{array}$ & $\begin{array}{c}-0.080^{* * *} \\
{[0.011]}\end{array}$ & $\begin{array}{c}-0.080^{* * *} \\
{[0.011]}\end{array}$ \\
\hline hunger age $00-16$ & $\begin{array}{c}0.492^{*} \\
{[0.282]}\end{array}$ & & & \\
\hline hunger age $00-16 \times \log \mathrm{HH}$ net income (lo) & $\begin{array}{l}-0.067^{*} \\
{[0.038]}\end{array}$ & & & \\
\hline hunger age $00-16 \times \log \mathrm{HH}$ net income (hi) & $\begin{array}{c}0.028 \\
{[0.033]}\end{array}$ & & & \\
\hline hunger age $00-03$ & & $\begin{array}{l}1.242^{* *} \\
{[0.485]}\end{array}$ & & \\
\hline hunger age $00-03 \times \log \mathrm{HH}$ net income (lo) & & $\begin{array}{c}-0.165^{* *} \\
{[0.065]}\end{array}$ & & \\
\hline hunger age $00-03 \times \log \mathrm{HH}$ net income (hi) & & $\begin{array}{l}-0.023 \\
{[0.042]}\end{array}$ & & \\
\hline hunger age $04-10$ & & & $\begin{array}{l}0.822^{* *} \\
{[0.358]}\end{array}$ & \\
\hline hunger age $04-10 \times \log \mathrm{HH}$ net income (lo) & & & $\begin{array}{c}-0.110^{* *} \\
{[0.048]}\end{array}$ & \\
\hline hunger age $04-10 \times \log \mathrm{HH}$ net income (hi) & & & $\begin{array}{c}0.045 \\
{[0.039]}\end{array}$ & \\
\hline hunger age $11-16$ & & & & $\begin{array}{c}0.319 \\
{[0.320]}\end{array}$ \\
\hline hunger age $11-16 \times \log \mathrm{HH}$ net income (lo) & & & & $\begin{array}{l}-0.048 \\
{[0.043]}\end{array}$ \\
\hline hunger age $11-16 \times \log \mathrm{HH}$ net income (hi) & & & & $\begin{array}{c}0.047 \\
{[0.041]}\end{array}$ \\
\hline Constant & $\begin{array}{l}-0.023 \\
{[0.191]}\end{array}$ & $\begin{array}{c}-0.008 \\
{[0.192]}\end{array}$ & $\begin{array}{l}-0.043 \\
{[0.189]}\end{array}$ & $\begin{array}{c}0.097 \\
{[0.194]}\end{array}$ \\
\hline Observations & 953 & 953 & 953 & 953 \\
\hline $\mathrm{R}^{2}$ & 0.190 & 0.188 & 0.190 & 0.198 \\
\hline
\end{tabular}


Table 4: OLS regression food share on threshold dummy $1500 \mathrm{kcal} /$ day, log net HH income, interaction terms and squared interaction terms, ages 0-16, 0-3, 4-10 and 11-16

\begin{tabular}{|c|c|c|c|c|}
\hline VARIABLES & $\begin{array}{c}\text { (1) } \\
\text { foodshare }\end{array}$ & $\begin{array}{c}\text { (2) } \\
\text { foodshare }\end{array}$ & $\begin{array}{c}\text { (3) } \\
\text { foodshare }\end{array}$ & $\begin{array}{c}\text { (4) } \\
\text { foodshare }\end{array}$ \\
\hline $\log \mathrm{HH}$ net income (lo) & $\begin{array}{c}-0.034^{* *} \\
{[0.016]}\end{array}$ & $\begin{array}{c}-0.051^{* * *} \\
{[0.013]}\end{array}$ & $\begin{array}{c}-0.036^{* *} \\
{[0.015]}\end{array}$ & $\begin{array}{c}-0.054^{* * *} \\
{[0.014]}\end{array}$ \\
\hline log HH net income (hi) & $\begin{array}{c}-0.093^{* * *} \\
{[0.013]}\end{array}$ & $\begin{array}{c}-0.080^{* * *} \\
{[0.012]}\end{array}$ & $\begin{array}{c}-0.083^{* * *} \\
{[0.013]}\end{array}$ & $\begin{array}{c}-0.080^{* * *} \\
{[0.011]}\end{array}$ \\
\hline ever bel $1500 \mathrm{kcal}$ age $00-16$ & $\begin{array}{c}0.311^{*} \\
{[0.161]}\end{array}$ & & & \\
\hline ever bel $1500 \mathrm{kcal}$ age $00-16 \times \log \mathrm{HH}$ net income (lo) & $\begin{array}{l}-0.041^{*} \\
{[0.021]}\end{array}$ & & & \\
\hline ever bel $1500 \mathrm{kcal}$ age $00-16 \times \log \mathrm{HH}$ net income (hi) & $\begin{array}{c}0.034^{*} \\
{[0.020]}\end{array}$ & & & \\
\hline ever bel $1500 \mathrm{kcal}$ age 00-03 & & $\begin{array}{c}0.169 \\
{[0.198]}\end{array}$ & & \\
\hline ever bel $1500 \mathrm{kcal}$ age $00-03 \times \log \mathrm{HH}$ net income (lo) & & $\begin{array}{c}-0.021 \\
{[0.027]}\end{array}$ & & \\
\hline ever bel $1500 \mathrm{kcal}$ age $00-03 \times \mathrm{x}$ log HH net income (hi) & & $\begin{array}{c}0.015 \\
{[0.024]}\end{array}$ & & \\
\hline ever bel $1500 \mathrm{kcal}$ age $04-10$ & & & $\begin{array}{l}0.421^{* *} \\
{[0.169]}\end{array}$ & \\
\hline ever bel $1500 \mathrm{kcal}$ age $04-10 \mathrm{x} \log \mathrm{HH}$ net income (lo) & & & $\begin{array}{c}-0.055^{* *} \\
{[0.023]}\end{array}$ & \\
\hline ever bel $1500 \mathrm{kcal}$ age $04-10 \times \log \mathrm{HH}$ net income (hi) & & & $\begin{array}{c}0.019 \\
{[0.021]}\end{array}$ & \\
\hline ever bel $1500 \mathrm{kcal}$ age $11-16$ & & & & $\begin{array}{c}0.140 \\
{[0.214]}\end{array}$ \\
\hline ever bel $1500 \mathrm{kcal}$ age $11-16 \mathrm{x}$ log HH net income (lo) & & & & $\begin{array}{c}-0.023 \\
{[0.029]}\end{array}$ \\
\hline ever bel $1500 \mathrm{kcal}$ age $11-16 \mathrm{x} \log \mathrm{HH}$ net income (hi) & & & & $\begin{array}{c}0.020 \\
{[0.037]}\end{array}$ \\
\hline Constant & $\begin{array}{c}-0.049 \\
{[0.207]}\end{array}$ & $\begin{array}{c}0.147 \\
{[0.207]}\end{array}$ & $\begin{array}{c}-0.043 \\
{[0.201]}\end{array}$ & $\begin{array}{c}0.241 \\
{[0.227]}\end{array}$ \\
\hline Observations & 953 & 953 & 953 & 953 \\
\hline $\mathrm{R}^{2}$ & 0.190 & 0.189 & 0.191 & 0.191 \\
\hline
\end{tabular}


Table 5: OLS Spousal Household Models for Childhood years 0-16

\begin{tabular}{|c|c|c|}
\hline VARIABLES & $\begin{array}{c}(1) \\
\text { Food share }\end{array}$ & $\begin{array}{c}(2) \\
\text { Food share }\end{array}$ \\
\hline log $\mathrm{HH}$ net income (lo) & $\begin{array}{c}-0.047^{\star \star *} \\
{[0.013]}\end{array}$ & $\begin{array}{c}-0.022 \\
{[0.017]}\end{array}$ \\
\hline log $\mathrm{HH}$ net income (hi) & $\begin{array}{c}-0.081^{\star \star *} \\
{[0.012]}\end{array}$ & $\begin{array}{c}-0.098^{\star \star \star} \\
{[0.014]}\end{array}$ \\
\hline hunger at age 0-16 & $\begin{array}{l}0.507^{\star} \\
{[0.292]}\end{array}$ & \\
\hline hunger at age $0-16$ spouse & $\begin{array}{c}0.540 \\
{[0.534]}\end{array}$ & \\
\hline hunger age $0-16 \times \log \mathrm{HH}$ net income (lo) & $\begin{array}{l}-0.070^{*} \\
{[0.039]}\end{array}$ & \\
\hline hunger age $0-16 \times \log \mathrm{HH}$ net income (hi) & $\begin{array}{c}0.028 \\
{[0.034]}\end{array}$ & \\
\hline hunger age $0-16 \times \log \mathrm{HH}$ net income (lo) of spouse & $\begin{array}{c}-0.071 \\
{[0.071]}\end{array}$ & \\
\hline hunger age $0-16 \times \log \mathrm{HH}$ net income (hi) of spouse & $\begin{array}{l}-0.009 \\
{[0.034]}\end{array}$ & \\
\hline cal ever below 1500 age 0-16 & & $\begin{array}{l}0.403^{\star \star} \\
{[0.175]}\end{array}$ \\
\hline cal ever below 1500 age $0-16$ of spouse & & $\begin{array}{l}0.688^{\star} \\
{[0.360]}\end{array}$ \\
\hline Cal ever below 1500 age $0-16 \times \log \mathrm{HH}$ net income (lo) & & $\begin{array}{c}-0.053^{\star \star} \\
{[0.023]}\end{array}$ \\
\hline Cal ever below 1500 age $0-16 \times \log \mathrm{HH}$ net income (hi) & & $\begin{array}{c}0.039^{\star} \\
{[0.022]}\end{array}$ \\
\hline Cal ever below 1500 age $0-16 \times$ log $\mathrm{HH}$ net income (lo) & use & $\begin{array}{l}-0.091^{*} \\
{[0.048]}\end{array}$ \\
\hline Cal ever below 1500 age $0-16 \times \log \mathrm{HH}$ net income (hi) & ouse & 0.046 \\
\hline Observations & 953 & 953 \\
\hline R-squared & 0.192 & 0.195 \\
\hline
\end{tabular}


Table 6: OLS regression probability of being obese on threshold dummy $1500 \mathrm{kcal} / \mathrm{day}$, log net $\mathrm{HH}$ income, interaction terms and squared interaction terms, ages $0-16,0-3,4-10$ and 11-16
(1)
(2)
(3)
(4)

VARIABLES

$\log \mathrm{HH}$ net income (lo)

$\log \mathrm{HH}$ net income (hi)

hunger age 00-16

hunger age 00-16 x log HH net income (lo)

hunger age 00-16 x log HH net income (hi)

hunger age 00-03

hunger age $00-03 \times \log \mathrm{HH}$ net income (lo)

hunger age 00-03 x log HH net income (hi)

hunger age 04-10

hunger age $04-10 \times \log \mathrm{HH}$ net income (lo)

hunger age $04-10 \times \log \mathrm{HH}$ net income (hi)

hunger age 11-16

hunger age $11-16$ x log HH net income (lo)

hunger age 11-16 x log HH net income (hi)

Constant

$2.295^{* *}$

[1.085]
$-0.124^{*}$
[0.072]
$-0.169 * * *$
[0.042]
$3.724^{*}$
[1.949]
$-0.487^{*}$
[0.258]
0.090
[0.162]

$-0.142^{* *}$

$-0.139 *$

$-0.135^{*}$

[0.071]

[0.072]

[0.072]

$-0.163^{* * *}$

$-0.156^{* * *}$

$-0.176^{* * *}$

[0.041]

[0.042]

[0.042]

$6.493^{* *}$

[3.292]

$-0.846^{*}$

[0.445]

$-0.079$

[0.336]

$$
\begin{gathered}
5.111^{* *} \\
{[2.378]} \\
-0.661^{* *} \\
{[0.314]} \\
-0.022 \\
{[0.180]}
\end{gathered}
$$

2.751

[2.604]

$-0.385$

[0.344]

0.282

[0.194]

$2.615^{* *}$

$2.677^{* *}$

$2.838^{* * *}$

[1.092]

\begin{tabular}{lcccc} 
Observations & 850 & 850 & 850 & 850 \\
$\mathrm{R}^{2}$ & 0.044 & 0.043 & 0.047 & 0.044 \\
\hline Standard errors are clustered on the household level. ${ }^{* * *} \mathrm{p}<0.01,{ }^{* *} \mathrm{p}<0.05,{ }^{*} \mathrm{p}<0.1$ & & \\
We control for age, age ${ }^{2}$, gender, born in rural/urban region, and household size.
\end{tabular}




\section{Figures}

Figure 1: self-reported hunger by SHARE countries, 1920-1960

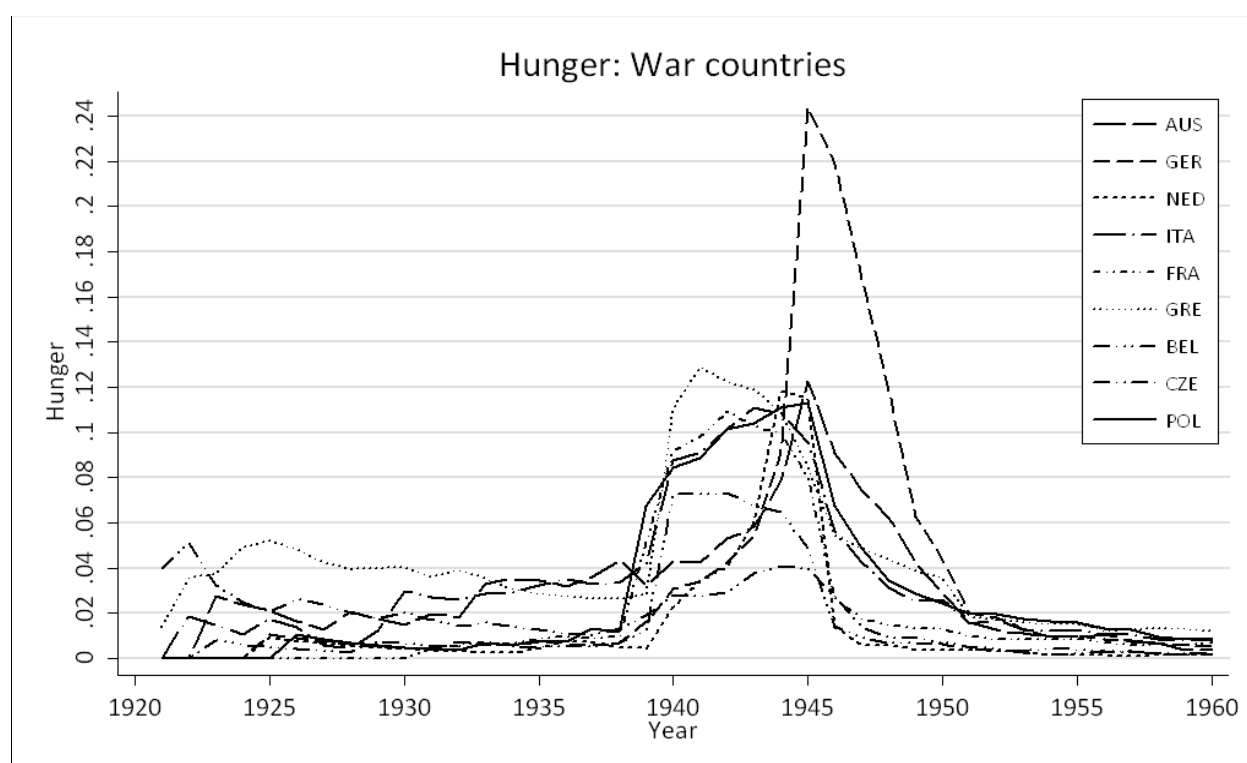

Figure 2: amount of official caloric intake per day plotted against the fraction of selfreported hunger2, January 1930-January 1970

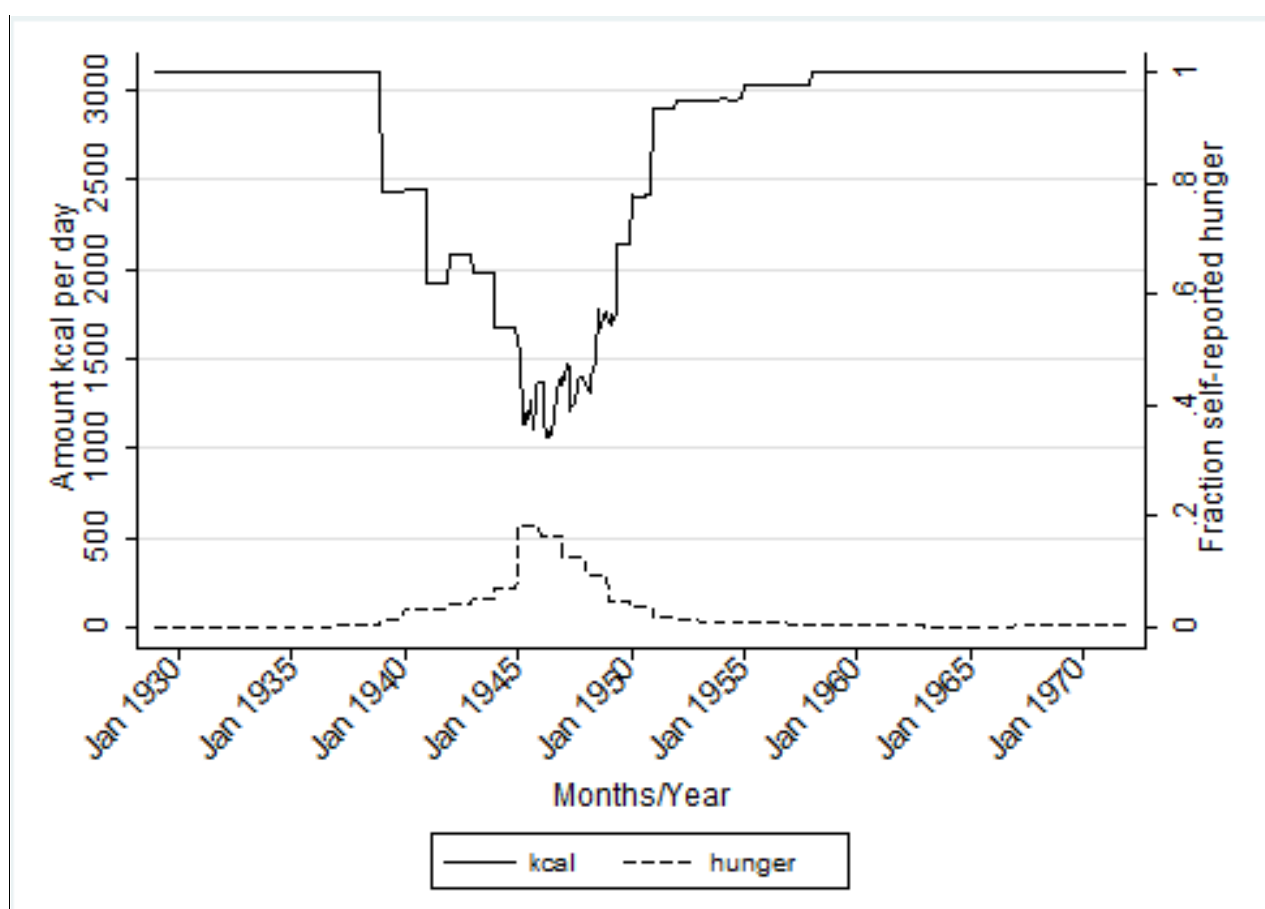


Figure 3: fraction of self-reported hunger by socioeconomic status, $1930-1960$

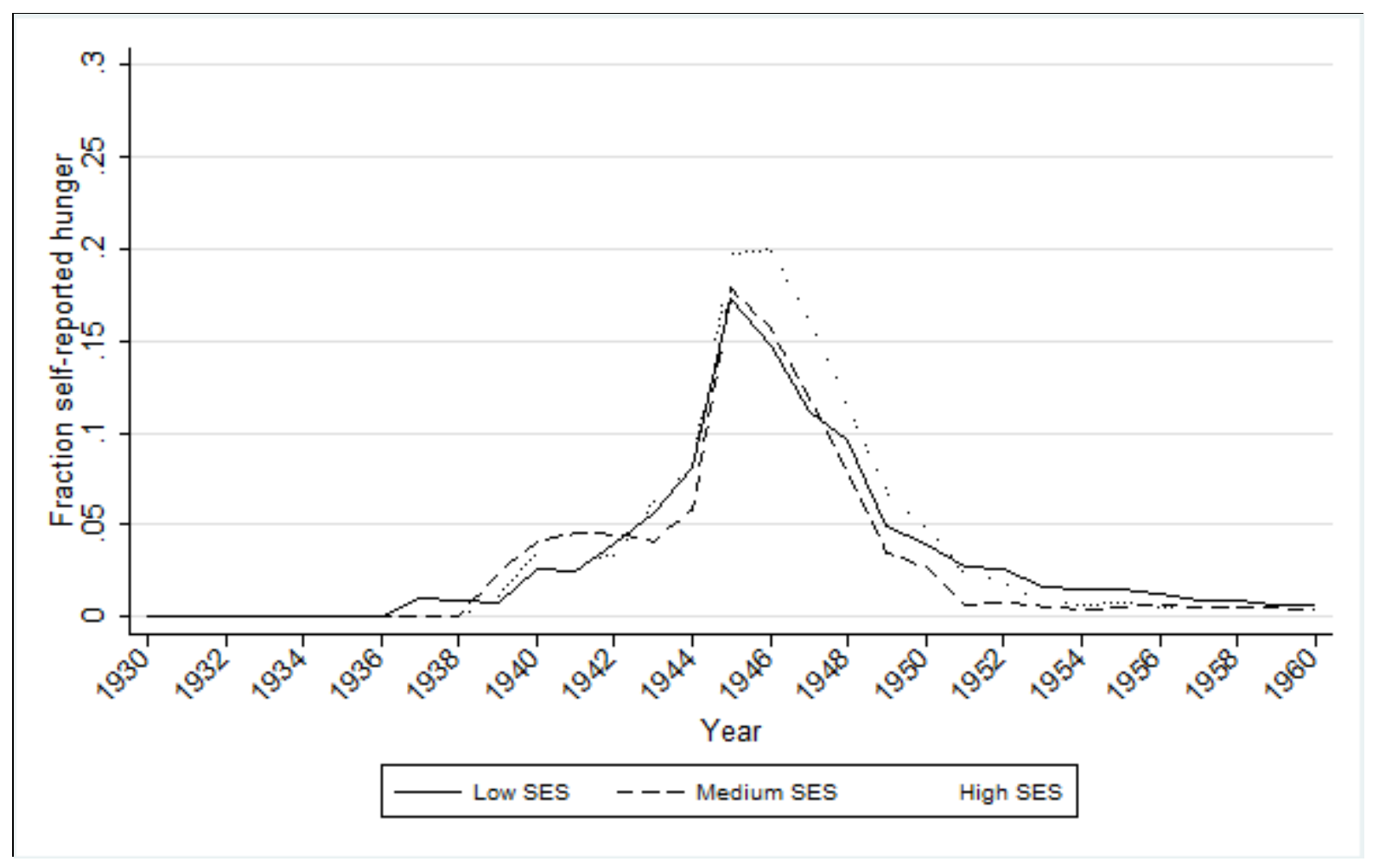


Figure 4: food share predictions from OLS regression plotted against log household net income splines by self-reported hunger and ever below $1500 \mathrm{kcal} /$ day at age 0-16

(a) income splines: suffered from hunger according to self-reported hunger

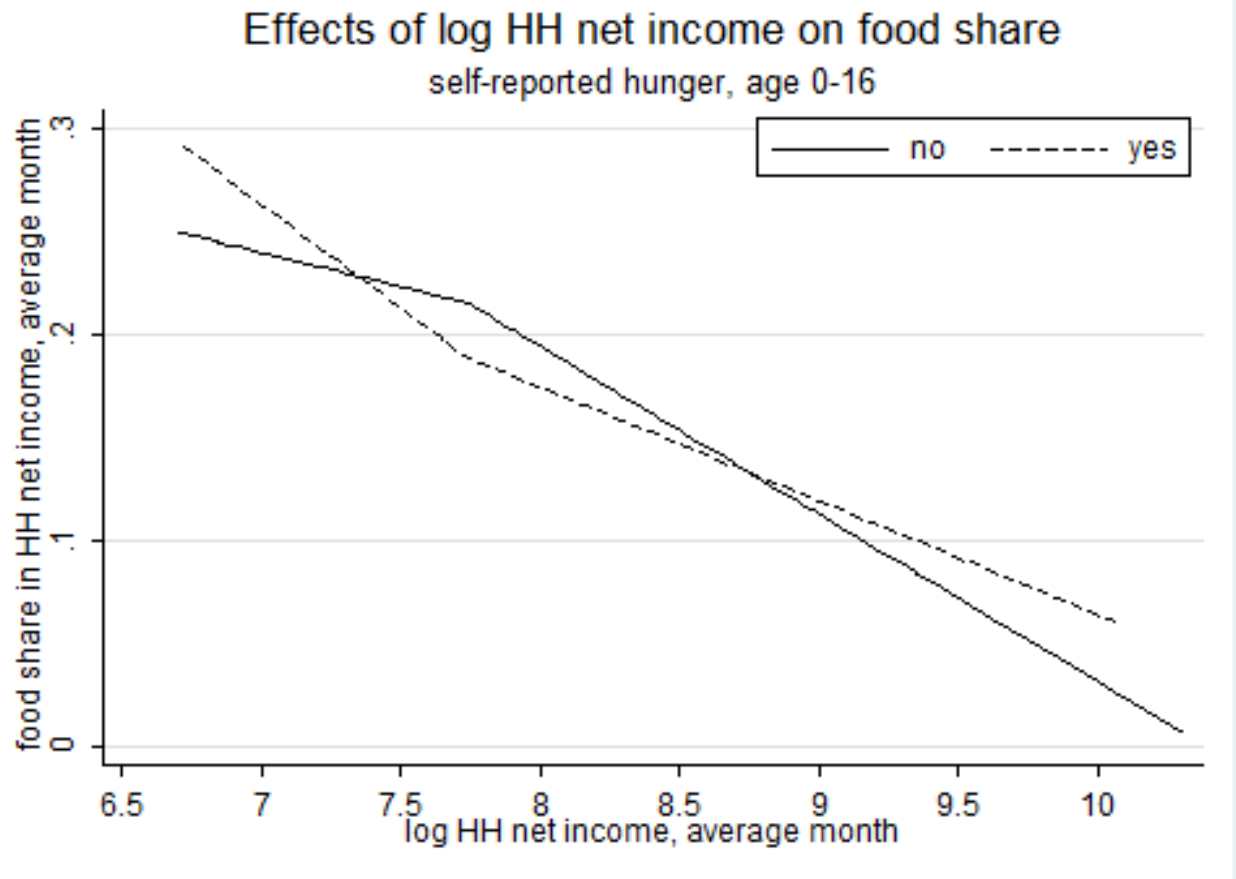

(b) income splines: suffered from hunger according to having experienced at least one month below $1500 \mathrm{kcal}$

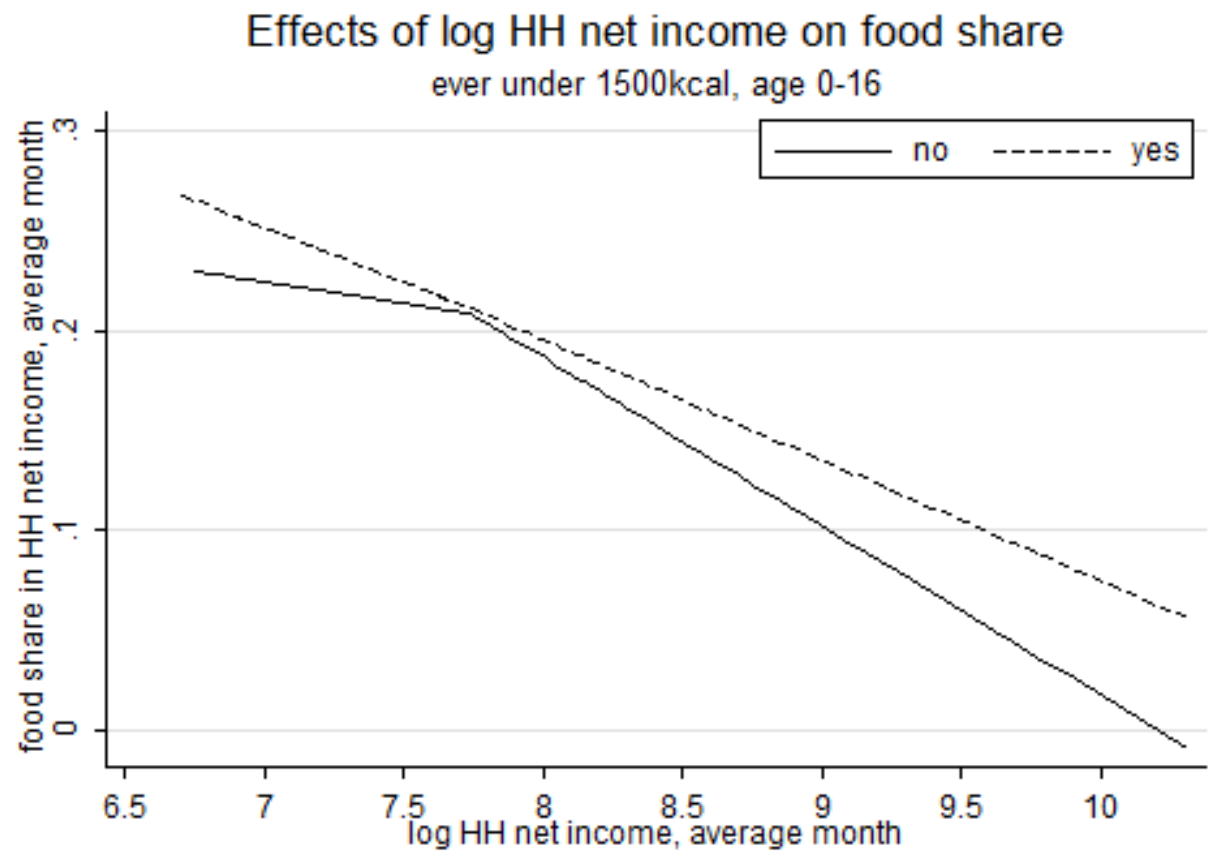




\section{References}

Almond, D. and J. Currie (2011): Killing Me Softly: The fetal origins hypothesis. Journal of Economic Perspectives 25(3), 153-172.

Banks, J., R. Blundell, and Arthur Lewbel (1997): Quadratic Engel curves and consumer demand. The Review of Economics and Statistics 79(4), 527-539.

Barker, D.J.B. (1992): Fetal and infant origins of adult disease. BMJ Publishing Group, London.

Barker, D.J.B. (2004): The developmental origins of adult disease. Journal of the American College of Nurtition, 23(6), 588S-595S.

Basset, G., and R. Koenker (1978): Regression Quantiles. Econometrica 46(1), 33-50.

Blundell, R., X. Chen, and D. Kristensen (2007): Semi-nonparametric IV estimation of shapeinvariant Engel curves. Econmetrica 75(6), 1613-1669.

Boldorf, M. (1998): Sozialfuersorge in der SBZ/DDR 1945-1953. Ursachen, Ausmass und Bewaeltigung der Nachkriegsarmut. Franz Steiner Verlag

Dohmen, T., A. Falk, D. Huffman, and U. Sunde (2011): The intergenerational transmission of risk and trust attitudes. Review of Economic Studies, 79(2), 645-677.

Eitner, H.J. (1991): Hitlers Deutsche. Das Ende eines Tabus. Casimir Katz Verlag.

Farquharson, J.E. (1985): The Western Allies and Politics of Food. Agrarian Management in Postwar Germany. Berg Publishers.

Haeusser, A. and G. Maugg (2011): Hungerwinter: Deutschlands humanitaere Katastrophe 1946/47. List Taschenbuch.

Halmdienst, N. and R. Winter-Ebmer (2012): Long-run effects of childhood shocks on health in adulthood. Presentation at the CESifo Conference on Families, Children and Human Capital Formation, Munich, October.

Havari, E. and F. Peracchi (2011): Childhood circumstances and adult outcomes: Evidence from SHARELIFE. EIEF Working Paper 1115, Einaudi Institute for Economic and Finance (EIEF).

Heckman, J. J. (2012): The developmental origins of health. Health Economics, 21(1), 24-29.

Jürges, H. (2013): Collateral damage: Educational attainment and labor market outcomes among German war and post-war cohorts. Journal of Health Economics, forthcoming. 
Kesternich, I., B. Siflinger, J. P. Smith, and J. K. Winter (2012): The effects of World War II on economic and health outcomes across Europe Review of Economics and Statistics, forthcoming.

Kulischer, E.M. (1948): Europe on the move: war and population changes 1917-47. Columbia University Press.

Lewbel A. (2010): Shape-invariant demand functions. The Review of Economics and Statistics 92(3), 549-556.

Liebe, H. (1947): Drei Grundprobleme der deutschen Wirtschaft. In: DIW (eds.), Die deutsche Wirtschaft zwei Jahre nach dem Zusammenbruch. Tatsachen und Probleme. Berlin, Nauck.

Lumey, L.H. and A.D. Stein (1997): In utero exposure to famine and subsequent fertility: The Dutch Famine Birth Cohort Study. American Journal of Public Health 87(12), 19621966.

Mazzonna, F. (2011): The long-lasting effects of family background: A European crosscountry comparison, MEA discussion paper series 11245.

Roodman, D. (2009): Estimating fully observed recursive mixed-process models with $\mathrm{cmp}$. CGD working paper No 168.

Rothenberger, K. (1980): Die Hungerjahre nach dem Zweiten Weltkrieg. Boldt Verlag.

Schlange-Schoeningen, H. (1955): Im Schatten des Hungers. Dokumentarisches zur Ernaehrungspolitik und Ernaehrungswirtschaft in den Jahren 1945-1949. P. Parey.

Schwarzer, O. (1995): Der Lebensstandard in der SBZ/DDR 1945-1989, in: Jahrbuch für Wirtschaftsgeschichte 1995(2), 119-146.

Silbernagl, S. and A. Despopoulos (1988): Taschenatlas der Physiologie. Thieme Verlag.

Smith, James P. (1999): Healthy bodies and thick wallets. Journal of Economic Perspectives 13(2), 145-166.

Stein, Z., M. Susser, G. Saenger, and F. Marolla (1975): Famine and human development-the dutch hunger winter of 1944-1945. Oxford University Press.

Van den Berg, G., P.A. Pinger, and J. Schoch (2012): Instrumental variable estimation of the causal effect of hunger early in life on health later in life. ZEW Discussion Paper No. 12-019.

Waite, L.J., 1995. Does marriage matter? Demography 32 (4), 483-507. 


\section{Appendix}

Table A.1: Median regression food share on self-reported hunger, splines (median split) of log net $\mathrm{HH}$ income, and interaction terms, age $0-16,0-3,4-10$, and 11-16

\begin{tabular}{|c|c|c|c|c|}
\hline VARIABLES & $\begin{array}{c}\text { (1) } \\
\text { foodshare }\end{array}$ & $\begin{array}{c}\text { (2) } \\
\text { foodshare }\end{array}$ & $\begin{array}{c}\text { (3) } \\
\text { foodshare }\end{array}$ & $\begin{array}{c}\text { (4) } \\
\text { foodshare }\end{array}$ \\
\hline log HH net income (lo) & $\begin{array}{c}-0.054^{* * *} \\
{[0.017]}\end{array}$ & $\begin{array}{c}-0.062^{* * *} \\
{[0.016]}\end{array}$ & $\begin{array}{c}-0.056^{* * *} \\
{[0.017]}\end{array}$ & $\begin{array}{c}-0.059^{* * *} \\
{[0.016]}\end{array}$ \\
\hline log HH net income (hi) & $\begin{array}{c}-0.095^{* * *} \\
{[0.016]}\end{array}$ & $\begin{array}{c}-0.092^{* * *} \\
{[0.015]}\end{array}$ & $\begin{array}{c}-0.095^{* * *} \\
{[0.016]}\end{array}$ & $\begin{array}{c}-0.090^{* * *} \\
{[0.016]}\end{array}$ \\
\hline hunger age $00-16$ & $\begin{array}{c}0.540^{*} \\
{[0.288]}\end{array}$ & & & \\
\hline hunger age $00-16 \times \log \mathrm{HH}$ net income (lo) & $\begin{array}{l}-0.075^{*} \\
{[0.038]}\end{array}$ & & & \\
\hline hunger age $00-16 \times \log \mathrm{HH}$ net income (hi) & $\begin{array}{c}0.029 \\
{[0.039]}\end{array}$ & & & \\
\hline hunger age $00-03$ & & $\begin{array}{c}1.786^{* * *} \\
{[0.289]}\end{array}$ & & \\
\hline hunger age $00-03 \times \log \mathrm{HH}$ net income (lo) & & $\begin{array}{c}-0.237^{* * *} \\
{[0.039]}\end{array}$ & & \\
\hline hunger age $00-03 \times \log \mathrm{HH}$ net income (hi) & & $\begin{array}{c}0.017 \\
{[0.047]}\end{array}$ & & \\
\hline hunger age $04-10$ & & & $\begin{array}{c}1.251^{* * *} \\
{[0.399]}\end{array}$ & \\
\hline hunger age $04-10 \times \log \mathrm{HH}$ net income (lo) & & & $\begin{array}{c}-0.167^{* * *} \\
{[0.053]}\end{array}$ & \\
\hline hunger age $04-10 \times \log \mathrm{HH}$ net income (hi) & & & $\begin{array}{c}0.065 \\
{[0.045]}\end{array}$ & \\
\hline hunger age $11-16$ & & & & $\begin{array}{l}0.707^{* *} \\
{[0.318]}\end{array}$ \\
\hline hunger age $11-16 \times \log \mathrm{HH}$ net income (lo) & & & & $\begin{array}{c}-0.100^{* *} \\
{[0.043]}\end{array}$ \\
\hline hunger age $11-16 \times \log \mathrm{HH}$ net income (hi) & & & & $\begin{array}{c}0.054 \\
{[0.047]}\end{array}$ \\
\hline Constant & $\begin{array}{c}0.105 \\
{[0.204]}\end{array}$ & $\begin{array}{c}0.009 \\
{[0.213]}\end{array}$ & $\begin{array}{c}0.028 \\
{[0.216]}\end{array}$ & $\begin{array}{c}0.209 \\
{[0.212]}\end{array}$ \\
\hline Observations & 953 & 953 & 953 & 953 \\
\hline
\end{tabular}


Table A.2: Median regression food share threshold dummy $1500 \mathrm{kcal} / \mathrm{day}$, splines (median split) of log net $\mathrm{HH}$ income, and interaction, age $0-16,0-3,4-10$, and 11-16

\begin{tabular}{|c|c|c|c|c|}
\hline VARIABLES & $\begin{array}{c}\text { (1) } \\
\text { foodshare }\end{array}$ & $\begin{array}{c}\text { (2) } \\
\text { foodshare }\end{array}$ & $\begin{array}{c}\text { (3) } \\
\text { foodshare }\end{array}$ & $\begin{array}{c}\text { (4) } \\
\text { foodshare }\end{array}$ \\
\hline log HH net income (lo) & $\begin{array}{c}-0.052^{* *} \\
{[0.021]}\end{array}$ & $\begin{array}{c}-0.055^{* * *} \\
{[0.017]}\end{array}$ & $\begin{array}{c}-0.041^{* *} \\
{[0.019]}\end{array}$ & $\begin{array}{c}-0.064^{* * *} \\
{[0.020]}\end{array}$ \\
\hline log HH net income (hi) & $\begin{array}{c}-0.092^{* * *} \\
{[0.014]}\end{array}$ & $\begin{array}{c}-0.092^{* * *} \\
{[0.015]}\end{array}$ & $\begin{array}{c}-0.102^{* * *} \\
{[0.013]}\end{array}$ & $\begin{array}{c}-0.086^{* * *} \\
{[0.015]}\end{array}$ \\
\hline ever bel $1500 \mathrm{kcal}$ age $00-16$ & $\begin{array}{c}0.378 \\
{[0.248]}\end{array}$ & & & \\
\hline ever bel $1500 \mathrm{kcal}$ age $00-16 \times \log \mathrm{HH}$ net income (lo) & $\begin{array}{c}-0.049 \\
{[0.033]}\end{array}$ & & & \\
\hline ever bel $1500 \mathrm{kcal}$ age $00-16 \times \log \mathrm{HH}$ net income (hi) & $\begin{array}{c}0.038 \\
{[0.025]}\end{array}$ & & & \\
\hline ever bel $1500 \mathrm{kcal}$ age $00-03$ & & $\begin{array}{c}0.309 \\
{[0.401]}\end{array}$ & & \\
\hline ever bel $1500 \mathrm{kcal}$ age $00-03 \times \log \mathrm{HH}$ net income (lo) & & $\begin{array}{c}-0.039 \\
{[0.054]}\end{array}$ & & \\
\hline ever bel $1500 \mathrm{kcal}$ age $00-03 \times \log \mathrm{HH}$ net income (hi) & & $\begin{array}{c}0.033 \\
{[0.029]}\end{array}$ & & \\
\hline ever bel $1500 \mathrm{kcal}$ age $04-10$ & & & $\begin{array}{l}0.554^{* *} \\
{[0.265]}\end{array}$ & \\
\hline ever bel 1500 kcal age $04-10 \times \log \mathrm{HH}$ net income (lo) & & & $\begin{array}{c}-0.074^{* *} \\
{[0.035]}\end{array}$ & \\
\hline ever bel $1500 \mathrm{kcal}$ age $04-10 \times \log \mathrm{HH}$ net income (hi) & & & $\begin{array}{l}0.049^{* *} \\
{[0.024]}\end{array}$ & \\
\hline ever bel $1500 \mathrm{kcal}$ age $11-16$ & & & & $\begin{array}{c}0.015 \\
{[0.299]}\end{array}$ \\
\hline ever bel $1500 \mathrm{kcal}$ age $11-16 \mathrm{x} \log \mathrm{HH}$ net income (lo) & & & & $\begin{array}{c}-0.005 \\
{[0.040]}\end{array}$ \\
\hline ever bel $1500 \mathrm{kcal}$ age $11-16 \mathrm{x} \log \mathrm{HH}$ net income (hi) & & & & $\begin{array}{l}-0.024 \\
{[0.041]}\end{array}$ \\
\hline Constant & $\begin{array}{c}0.115 \\
{[0.234]}\end{array}$ & $\begin{array}{c}0.255 \\
{[0.226]}\end{array}$ & $\begin{array}{c}-0.062 \\
{[0.221]}\end{array}$ & $\begin{array}{c}0.286 \\
{[0.254]}\end{array}$ \\
\hline
\end{tabular}

Observations

953

953

953

953

Standard errors are clustered on the household level and have been calculated according to Machado and Santos Silva (2013). ${ }^{* * *} \mathrm{p}<0.01$, ${ }^{* *} \mathrm{p}<0.05,{ }^{*} \mathrm{p}<0.1$

We control for age, age ${ }^{2}$, gender, born in rural/urban region, Eastern Germany and household size. 